\title{
Pola Pembentukan Perilaku Anak Melalui Ritual Peta Ega: Studi Deskriptif pada Budaya Masyarakat Tidore
}

\author{
Rahmi A.Radjak ${ }^{1 *}$, Sitti Ummi Novi Rizka \\ ${ }^{1}$ TK Pertiwi Soa-Sio Tidore, Indonesia \\ ${ }^{2}$ SMPN 5 Tidore, Indonesia \\ *onchorabmi@gmail.com
}

\begin{abstract}
Indonesia is one of the great nations and countries. Indonesia has a unique cultural diversity or diversity. This diversity is reflected in various fields of life, including the arts, social and family fields. In the family, cultural patterns have a role in influencing rituals in the family, one of which is the ritual the birth of a baby. The Peta Ega Ritual is a ritual to welcoming the birth of a baby in Tidore Island and North Maluku communities. The Ega Map ritual has its peculiarities. The people of Tidore believe that suggestions through the Peta Ega ritual can have an impact on children's behavior in the future. The Peta Ega ritual itself has a element of suggestion given by parents or pious people to the baby. The approach in this research is qualitative with descriptive methods. Respondents from communities on the island of Tidore. The pattern of forming children's behavior in the Peta Ega ritual is carried out in two ways, that is direct suggestions given directly and indirectly. Direct suggestions are given by people who Peta Ega to the baby, while indirect suggestions are through suggestions on the placenta and behavioral associations given by parents and close relatives that are repeated repeatedly until the baby grows up. The words of suggestion are also considered as prayers that strengthen children's behavior:
\end{abstract}

\section{Abstrak}

Indonesia adalah salah satu bangsa dan negara besar. Indonesia memiliki keanekaragaman atau keragaman budaya yang unik. Keberagaman ini tercermin dalam berbagai bidang kehidupan, termasuk bidang seni, sosial, dan kekeluargaan. Di dalam keluarga, pola budaya berperan dalam mempengaruhi ritual dalam keluarga, salah satunya adalah ritual kelahiran bayi. Ritual Peta Ega merupakan ritual penyambutan kelahiran bayi di masyarakat Pulau Tidore dan Maluku Utara. Ritual Peta Ega memiliki kekhasan tersendiri. Masyarakat Tidore percaya bahwa sugesti melalui ritual Peta Ega dapat berdampak pada perilaku anak di masa depan. Ritual Peta Ega sendiri memiliki unsur sugesti yang diberikan oleh orang tua atau orang yang shalih kepada sang buah hati. Pendekatan dalam penelitian ini adalah kualitatif dengan metode deskriptif. Responden dari masyarakat di Pulau Tidore. Pola pembentukan tingkah laku anak dalam ritual Peta Ega dilakukan dengan dua cara, yaitu sugesti langsung yang diberikan secara langsung dan tidak langsung. Secara
Article Information:

Received Maret 12, 2021

Revised Maret 25, 2021

Accepted Maret 30, 2021

Keywords: Peta Ega;

Children's Behavior; Sugesti

Kata Kunci: Peta Ega; Perilaku Anak; Sugesti

How to cite: Radjak, R. A., \& Hasan, S. U. N. (2021). Pola Pembentukan Perilaku Anak Melalui Ritual Peta Ega: Studi Deskriptif pada Budaya Masyarakat Tidore. Prophetic Guidance and Counseling Journal, 2(1). doi: 10.32832/progcj.v2i1.5151

E-ISSN: 2614-1566

Published by: LPPM Universitas Ibn Khaldun Bogor \& Program Studi BKPI UIKA 
langsung diberikan oleh orang yang mempeta ega peta pada bayi, sedangkan sugesti tidak langsung melalui sugesti pada ari-ari bayi dan asosiasi perilaku yang diberikan oleh orang tua dan kerabat dekat yang diulang-ulang hingga bayi tumbuh besar. Kata-kata sugesti juga dianggap sebagai doa yang menguatkan perilaku anak

\section{Pendahuluan}

Indonesia adalah salah satu bangsa dan negara yang besar. Indonesia memiliki kemajemukan atau keanekaragaman budaya yang khas. Keanekaragaman tersebut tercermin dalam berbagai bidang kehidupan, di antaranya bidang seni, bidang kemasyarakatan dan bidang keluarga. Dalam keluarga pola budaya memiliki peran yang kuat dalam mempengaruhi ritual dalam keluarga itu sendiri, seperti penyelenggaraan sunatan, sambutan anak yang berulang tahun, penyelenggaraan anak yang memasuki masa pubertas dan penyambutan kelahiran bayi.

Dalam penyelenggaraan penyambutan kelahiran bayi, hampir seluruh suku di Indonesia memiliki ciri khas yang berbeda dalam penyambutan kelahiran si buah hati, misalnya tradisi Njegong dan Sepasaran pada budaya Jawa (Sholikin, 2010: 110. Ritual dan Tradisi Islam Jawa, Narasi; Jakarta). Demikian pada suku Tidore Provinsi Maluku Utara. Seperti suku-suku lain di Indonesia, masyarakat Tidore meyakini bahwa kelahiran bayi merupakan peristiwa sakral yang harus diselenggarakan secara khusus. Dari keyakinan tersebut muncul kemudian ritual Peta Ega.

Ritual Peta Ega merupakan ritual penyambutan kelahiran bayi yang hampir dilakukan di seluruh kalangan masyarakat Tidore dan Maluku Utara. Ritual Peta Ega memiliki kekhasan dan keyakinan tersendiri. Masyarakat Tidore meyakini bahwa sugesti melalui ritual Peta Ega dapat berdampak pada perilaku anak kelak. Ritual Peta Ega sendiri memiliki unsur sugesti yang sangat kuat yang diberikan oleh orang tua atau orang saleh kepada si buah hati.

Kata-kata sugesti yang digunakan pada bayi secara langsung memiliki pengaruh kepada alam bawah sadar bayi. Menurut Trinurmi (2014:26) sugesti memiliki kemampuan pemrograman alam bawah sadar manusia. Pengaruh tersebut secara langsung berdampak pada sikap dan perilaku anak. Ritual Peta Ega adalah proses pemberian sugesti atau katakata positif kepada air-ari sang bayi oleh orang tertentu yang dipilih oleh orang tua bayi. Orang yang terpilih sebagai yang mem-peta ega adalah orang-orang yang dianggap memiliki karakter atau akhlak yang baik oleh orang tua atau keluarga sang bayi. Orang tua meyakini bahwa karakter yang baik serta kalimat-kalimat positif dari orang yang mem-peta ega akan berdampak pada perilaku bayi di masa mendatang.

Sugesti yang diberikan kepada bayi terbagi dua (Kahija, 2007: 109) menegaskan bahwa sugesti terbagi dua, yaitu sugesti langsung dan sugesti tidak langsung. Sugesti langsung diberikan melalui kata-kata kepada bayi, sedangkan sugesti tidak langsung melalui asosiasi perilaku dan ucapan kepada ari-ari. Dalam ritual Peta Ega, keyakinan dari orang tua atau kerabat dekat dilakukan secara konsisten dan berkala seperti mengasosiasi perilaku anak dengan orang yang mem-peta ega sehingga memperkuat alam bawah sadar yang telah ditanamkan di masa Peta Ega. Proses asosiasi ini merupakan bentuk sugesti tidak langsung kepada anak.

Oleh karena itu, penelitian ini bertujuan untuk meneliti pola perilaku yang dibentuk berdasarkan prosesi pada ritual Peta Ega. Apakah terdapat keselarasan antara sugesti dari orang yang mem-Peta Ega dengan bayi. Selanjutnya penelitian ini diharapkan memiliki kebermanfaatan untuk menghasilkan temuan-temuan baru melalui kearifan lokal dalam 
ritual budaya bangsa khususnya di Tidore yang dapat berkontribusi terhadap pengembangan ilmu pengetahuan khususnya dalam bidang psikologi anak.

\section{Metode Penelitian}

Metode penelitian yang digunakan adalah metode kuantitatif. Sugiyono (dalam Rusdi Kasman, 2013) mengemukakan bahwa di mana peneliti akan mengumpulkan data dengan menggunakan angket, sedangkan pendekatan yang digunakan adalah pendekatan deskriptif di mana peneliti akan menggambarkan data apa adanya untuk menarik kesimpulan.

Lokasi penelitian adalah di daerah Tidore Provinsi Maluku Utara. Responden atau populasi. Jumlah sampel yang diteliti berjumlah 59 orang yang diambil secara acak dan representatif dari desa-desa yang ada di Tidore. Sampel yang diambil dibatasi pada individu yang telah menikah dan memiliki anak. Teknik pengumpulan data yang digunakan adalah angket, sedangkan instrumen yang digunakan adalah pedoman angket.

Teknik pengolahan data adalah data yang telah dikumpulkan dari angket akan dideskripsikan kemudian dihitung persentasenya untuk menentukan aspek apa yang paling dominan untuk menarik kesimpulan secara deskriptif.

\section{Hasil dan Pembahasan}

Penelitian ini berfokus pada dua rumusan permasalahan yaitu bagaimana prosesi Ritual Peta Ega dan apakah terdapat dampak Ritual Peta Ega terhadap pola perilaku anak.

\section{A. Prosesi Ritual Peta Ega}

Prosesi Ritual Peta Ega adalah salah satu rangkaian prosesi penyambutan kelahiran anak di Pulau Tidore. Prosesi ritual Peta Ega adalah proses pemberian sugesti atau kata-kata positif kepada air-ari sang bayi oleh orang tertentu yang dipilih oleh orang tua bayi. Orang yang terpilih sebagai yang mem-peta ega adalah orang-orang yang dianggap memiliki karakter atau akhlak yang baik oleh orang tua atau keluarga sang bayi.

Secara umum proses Peta Ega yang dilakukan melalui tahapan berikut: Pertama, Plasenta/Ari-Ari (Dodomi) dibersihkan atau dibungkus dengan kain putih. Kedua, Plasenta ditaruh di dalam batok kelapa lalu dibungkus lagi dengan kain putih. Ketiga, Plasenta yang sudah di bungkus kemudian digendong oleh orang yang mem-peta ega menggunakan kain seperti menggendong bayi. Kepala orang yang mem-peta ega ditutup dengan bagian kain gendongan dengan tujuan menutup pandangan orang. Keempat, Orang yang mem-peta ega berdiri di depan pintu ketika akan berangkat menguburkan atau menenggelamkan plasenta. Kemudian bershalawat ketika melangkah keluar. Kelima, Plasenta dikuburkan atau ditenggelamkan di laut. Di beberapa tempat, ketika menguburkan orang mem-peta ega memberi kalimat-kalimat sugesti positif kepada plasenta. (Gafur, 2021)

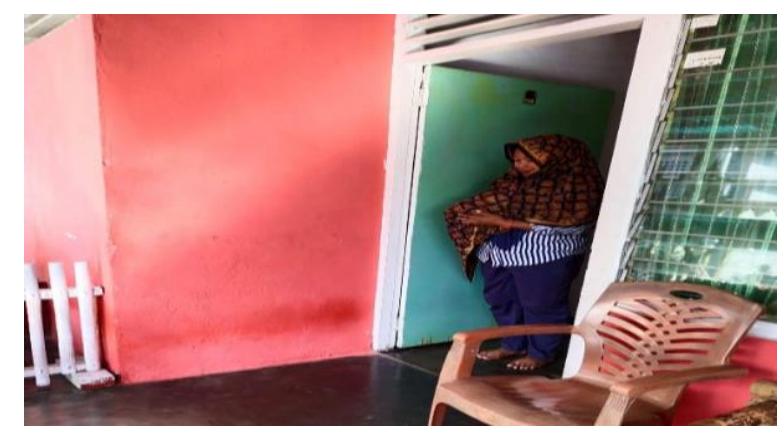

Gambar 1: Prosesi Mengeluarkan Plasenta oleh yang Mem-Peta Ega 


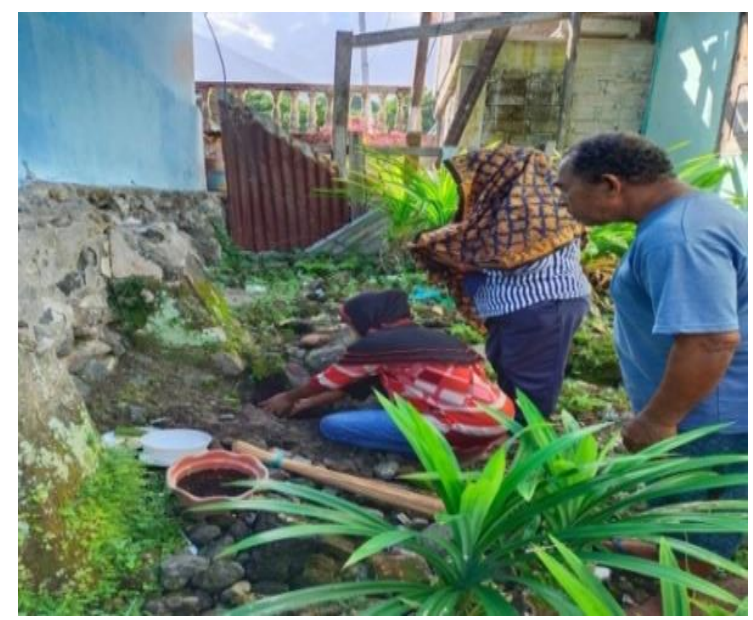

Gambar 2. Prosesi Penguburan Plasenta atau Dodomi

Dalam hasil riset responden yang perempuan yang mengisi angket sebanyak 42 orang, sedangkan orang, sedangkan responden laki-laki sebanyak 17 orang.

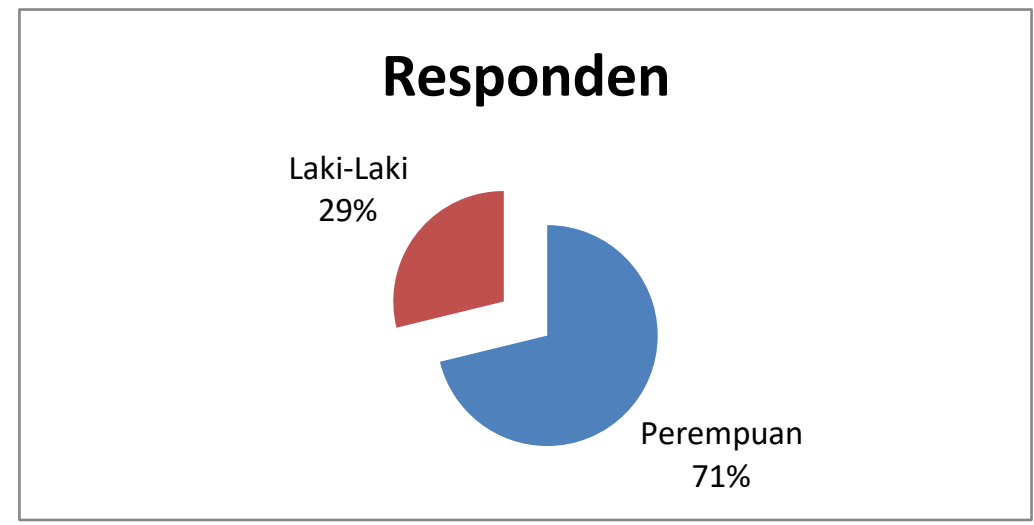

Diagram 1. Jumlah Responden

Proses pembentukan perilaku melalui dalam ritual Peta Ega terjadi melalui dua metode, yaitu metode sugesti menggunakan kata-kata secara langsung dan sugesti tidak langsung atau sugesti hetero (Trinurmi: 2014) di mana penguatan yang dilakukan oleh orang di sekitar bayi, seperti orang tua, anggota keluarga atau kerabat tetangga.

Dari 59 responden tersebut, 67,7\% meyakini jika sugesti dan karakter dari orang yang mem-Peta Ega sama dengan anaknya.

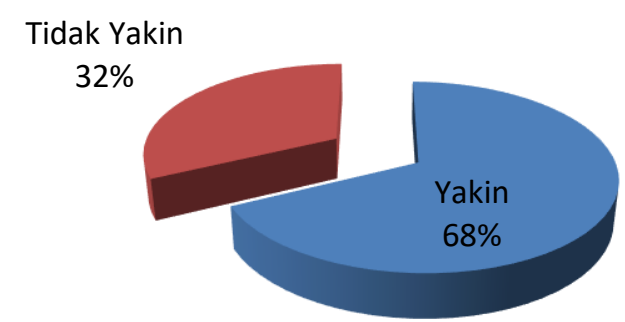

Diagram 2. Keyakinan Responden Terhadap Kesesuaian Sugesti Peta Ega 
Berdasarkan data di atas, bahwa keyakinan masyarakat terkait keselarasan perilaku anaknya dengan orang yang mem-peta ega memiliki tingkat kesesuaian yang tinggi.

Pola pembentukan perilaku anak melalui sugesti pada ritual Peta Ega terjadi karena penguatan yang dilakukan oleh orang sekitar pada bayi atau anak melalui asosiasi perilaku orang yang mem-peta ega. Dibandingkan dengan sugesti di masa bayi yang sebenarnya belum memiliki respons yang sempurna seperti orang dewasa. Penguatan ini dapat terlihat pada hasil penelitian tentang peran orang sekitar yang memberikan penguatan kepada bayi atau anak.

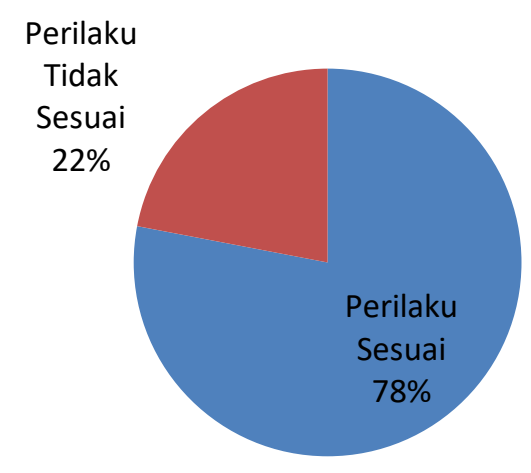

Diagram 3. Kesesuaian perilaku antara bayi dan pem-eta ega

Berdasarkan data penelitian di atas, pola pembentukan perilaku anak melalui ritual Peta Ega terjadi melalui sugesti terus-menerus yang dilakukan oleh orang sekitar dan pengaruh sugesti dari orang yang mem-peta ega. Hal tersebut memperkuat alam bawah sadar dan menjadi kalimat-kalimat doa yang kuat bagi anak.

Jadi Pola pembentukan perilaku anak melalui ritual Peta Ega melalui dua cara, yaitu sugesti yang diberikan secara langsung dan tidak langsung. Sugesti secara langsung diberikan oleh orang yang mempeta ega kepada bayi, sedangkan sugesti secara tidak langsung melalui sugesti pada ari-ari dan asosiasi perilaku yang diberikan orang tua dan kerabat dekat yang terus diulang-ulang hingga bayi itu tumbuh besar. Kalimat-kalimat sugesti tersebut dianggap pula sebagai doa yang memperkuat perilaku anak. Hal tersebut mengakibatkan pembentukan alam bawah sadar sang anak sehingga memperkuat perilaku tersebut.

Penelitian ini memiliki kelebihan dari pada penelitian pendahuluan yang hanya menggambarkan tradisi ritual penyambutan kelahiran saja. Sedangkan penelitian ini tidak hanya menggambarkan ritual kelahiran namun diikuti tahapan sugesti dan asosiasi pembentukan perilaku secara sistematis melalui kalimat doa dan sugesti.

\section{Kesimpulan}

Proses Ritual Peta Ega adalah proses pemberian sugesti atau kata-kata positif kepada air-ari sang bayi oleh orang tertentu yang dipilih oleh orang tua bayi. Orang yang terpilih sebagai yang mem-peta ega adalah orang-orang yang dianggap memiliki karakter atau akhlak yang baik oleh orang tua atau keluarga sang bayi. Secara umum proses Peta Ega yang dilakukan melalui tahapan berikut, Plasenta/Ari-Ari (Dodomi) dibersihkan atau dibungkus dengan kain putih, Plasenta ditaruh di dalam batok kelapa lalu dibungkus lagi dengan kain putih, Plasenta yang sudah dibungkus kemudian digendong oleh orang yang mem-peta ega menggunakan kain seperti menggendong bayi. Kepala orang yang mem-peta ega ditutup dengan bagian kain gendongan dengan tujuan menutup pandangan orang. Orang yang mem-peta ega berdiri di depan pintu ketika akan berangkat menguburkan atau 
menenggelamkan plasenta. Kemudian bershalawat ketika melangkah keluar dan terakhir Plasenta dikuburkan atau ditenggelamkan di laut. Di beberapa tempat, ketika menguburkan orang mem-peta ega memberi kalimat-kalimat sugesti positif kepada plasenta. Pola pembentukan perilaku anak melalui ritual Peta Ega melalui dua cara, yaitu sugesti yang diberikan secara langsung dan tidak langsung. Sugesti secara langsung diberikan oleh orang yang mempeta ega kepada bayi, sedangkan sugesti secara tidak langsung melalui sugesti pada ari-ari dan asosiasi perilaku yang diberikan orang tua dan kerabat dekat yang terus diulang-ulang hingga bayi itu tumbuh besar. Hal tersebut mengakibatkan pembentukan alam bawah sadar sang anak sehingga memperkuat perilaku tersebut.

\section{Daftar Pustaka}

Kahija. (2007). Hipnoterapi, Gramedia Pustaka Utama, Jakarta.

Koirun, L. (2019). Tradisi Larung Ari-Ari Sebagai Ritual Kelahiran Bayi di Kota Surakarta. Papers INA-RXIV

Petrus. (2019). Makna Ritual Adat Hapo Ana (Syukuran Bayi Lahir) Pada Masyarakat Jingitiu Di Desa Peddaro Kecamatan Hawu Mehara Kabupaten Sabu Raijua, Jurnal Gatranusantara, Volome 17, No. 2

Kasman, R. (2013). Program Bimbingan Pribadi Sosial untuk Meningkatkan Kecerdasan Moral Siswa, Jurnal Psikopedagogia, Volume 2, No. 1

Trinurmi, S. (2014). Pengaruh Sugesti dalam Pencapaian Hasil Belajar Siswa, Jurnal Al Irsyad An Nafs, Volume 1, Nomor 1.

Vivit \& Elis. (2018). Ritual Ngebuyu: Membumikan Pewaris Dan Perubahan Ritual Kelahiran Pada Marga Legun, Way Urang. Jurnal Imu Sosial dan Budaya, Volume 20 , No. 2

Isnain, M. (2021) Hasil Wawancara Tentang Proses Ritual Peta Ega. 